\title{
Outcome of partial cystectomy for non-urothelial urinary bladder malignancies in a tertiary care urology unit in Sri Lanka
}

\author{
Umesh Jayarajah, Kasun Herath, Manoj Hilary Fernando, Serozsha Goonewardena \\ Department of Urology, National Hospital of Sri Lanka, Colombo, Sri Lanka
}

Keywords: Partial cystectomy; non-urothelial urinary bladder malignancies; outcomes

\begin{abstract}
\section{Introduction}

Non-urothelial bladder cancers (NUBC) are very aggressive form of tumors and the standard treatment is radical cystectomy which is associated with high morbidity. This study was aimed to describe the outcome of partial cystectomy for selected patients with NUBC in a tertiary care urology unit in Sri Lanka.
\end{abstract}

\section{Methods}

A retrospective analysis of all patients $(n=7$, males $=4)$ who underwent partial cystectomy for NUBC in a tertiary care urology unit in National Hospital of Sri Lanka over a period of 16 years was done (From 2001 to 2016). All underwent preliminary transurethral resection of bladder tumour (TURBT), histological confirmation and imaging before partial cystectomy. Lymphadenectomy was performed in patients with macroscopic involvement.

\section{Results}

The median age was 59 years (range:40-71). Six patients had haematuria at presentation. Four patients had primary adenocarcinoma of the bladder. Others were leiomyosarcoma, small cell cancer and goblet cell carcinoid tumour. The majority had muscle invasive disease as confirmed by histopathology. The patients with signet ring cell carcinoma, leiomyosarcoma and well differentiated adenocarcinoma had favorable outcomes, while patients with papillary carcinoma, small cell carcinoma and goblet cell carcinoid tumour showed poor outcomes.

\section{Conclusion}

Partial cystectomy was associated with variable outcomes. Further analyses are necessary to understand the factors

Correspondence: Umesh Jayarajah

E-mail: umeshe.jaya@gmail.com

(iDhttps://orcid.org/0000-0002-0398-5197

Received: 14-11-2020 Accepted: 09-03-2021

DOI: http://doi.org/10.4038/sljs.v39i1.8740 associated with favorable outcomes which would be helpful in patient selection.

\section{Introduction}

Non-urothelial bladder cancers [NUBC] are a rare and generally aggressive form of tumours accounting for less than $5 \%$ of all bladder tumours $[1,2]$. Due to the rarity, the understanding of tumour behaviour and effective management strategies are poor. At present, the accepted surgical treatment is radical cystectomy which is associated with high morbidity and poor quality of life $[1,2]$. Furthermore, this may be unsuitable for elderly patients with significant comorbidities. Some patients refuse to undergo the surgery in our setting due to the associated functional morbidity. Therefore, such patients with NUBC with potentially resectable tumours were offered partial cystectomy. We report the outcome of partial cystectomy for selected patients with NUBC in a tertiary care urology unit in Sri Lanka.

\section{Methods}

Seven patients including 4 males and 3 females, who underwent partial cystectomy for non-urothelial bladder cancers in a tertiary care urology unit in National Hospital of Sri Lanka over a period of 16 years (From 2001 to 2016) were described. All patients underwent transurethral resection of the bladder tumour (TURBT) which was the standard procedure in the initial diagnosis and treatment of bladder cancer. Furthermore, histological confirmation and ultrasonography/ contrast enhanced computed tomography (CT) imaging was performed before partial cystectomy. Lymphadenectomy was performed in patients with macroscopic involvement. Details of patients were collected from hospital and clinic records. Ethical approval was obtained from the Ethics Review Committee of the National Hospital of Sri Lanka.

\section{Results}

Table 1 gives the summary of the 7 cases. The median age was 59 years [range: 34-71]. Six patients had haematuria at presentation. The majority of tumours were seen in the anterior wall and dome of the bladder. Four patients had primary adenocarcinoma of the bladder, of which one patient 
Table 1. Clinicopathological characteristics and outcome of patients who underwent partial cystectomy for non-urothelial bladder cancer

\begin{tabular}{|c|c|c|c|c|c|c|c|c|c|c|c|}
\hline Age & $\begin{array}{l}5 \\
e \\
x\end{array}$ & $\begin{array}{l}\text { Presentati } \\
\text { on }\end{array}$ & Imaging & Procedure & $\begin{array}{l}\text { Lympha } \\
\text { denect } \\
\text { omy }\end{array}$ & Histology & $\begin{array}{l}\text { Immunohistoch } \\
\text { emistry }\end{array}$ & Outcome & $\begin{array}{l}\text { Period } \\
\text { without } \\
\text { recurrence }\end{array}$ & $\begin{array}{l}\text { Period } \\
\text { without } \\
\text { progression }\end{array}$ & $\begin{array}{l}\text { Overall } \\
\text { survival }\end{array}$ \\
\hline 71 & $F$ & $\begin{array}{l}\text { Painless } \\
\text { haematur } \\
\text { a for } 2 \\
\text { months }\end{array}$ & $\begin{array}{l}\text { US5: } 2.1 \times \\
1.5 \times 1.5 \\
\mathrm{~cm} \\
\text { Anterior } \\
\text { bladder } \\
\text { wall } \\
\text { growth }\end{array}$ & $\begin{array}{l}\text { Partial } \\
\text { cystectomy }\end{array}$ & $\begin{array}{l}\text { Not } \\
\text { done }\end{array}$ & $\begin{array}{l}\text { PT2 signet ring } \\
\text { type primary } \\
\text { Adenocarcinoma } \\
\text { of the bladder. } \\
\text { No } \\
\text { lymphovascular } \\
\text { or perineural } \\
\text { invasion. }\end{array}$ & $\begin{array}{l}\text { Cytoplasm } \\
\text { positive for } \\
\text { CK2O and } \mathrm{CKO} 7 \\
\text { Nuclear } \\
\text { positivity for } \\
\text { CDX2 } \\
\text { Membrane } \\
\text { positivity for } \\
\text { beta-catenin }\end{array}$ & $\begin{array}{l}\text { Alive at } 20 \\
\text { months with } \\
\text { no } \\
\text { recurrence }\end{array}$ & $\begin{array}{l}>18 \\
\text { months }\end{array}$ & $>18$ months & $\begin{array}{l}>24 \\
\text { months }\end{array}$ \\
\hline 64 & $F$ & $\begin{array}{l}\text { Lower } \\
\text { abdominal } \\
\text { pain for } 3 \\
\text { months }\end{array}$ & $\begin{array}{l}\text { CECT: } \\
7.9 \times 6.9 \times 6 . \\
3 \mathrm{~cm} \text { mas5 } \\
\text { anterior } \\
\text { bladder } \\
\text { wall }\end{array}$ & $\begin{array}{l}\text { Partial } \\
\text { oystectomy }\end{array}$ & $\begin{array}{l}\text { Not } \\
\text { done }\end{array}$ & $\begin{array}{l}\text { PT3b Moderately } \\
\text { differentiated } \\
\text { adenocarcinoma } \\
\text { No } \\
\text { Lymphovascular } \\
\text { invasion. Tumour } \\
\text { necrosis present. }\end{array}$ & Not done & $\begin{array}{l}\text { No CT } \\
\text { evidence of } \\
\text { recurrence } \\
\text { at } 4 \text { months } \\
\text { and } \\
\text { asymptomati } \\
\text { c at } 9 \\
\text { months }\end{array}$ & 4 months & 4 months & $\begin{array}{l}\text { 9 } \\
\text { months } \\
\text { and } \\
\text { there } \\
\text { after } \\
\text { lost to } \\
\text { follow } \\
\text { up }\end{array}$ \\
\hline 40 & M & $\begin{array}{l}\text { Painless } \\
\text { haematuri } \\
\text { a for } 1 \\
\text { month }\end{array}$ & $\begin{array}{l}\text { U55: } 3.7 \times \\
2.8 \times 3.9 \\
\mathrm{~cm} \text { Dome } \\
\text { and } \\
\text { anterior } \\
\text { wall mass }\end{array}$ & $\begin{array}{l}\text { Partial } \\
\text { cystectomy } \\
\text { followed } \\
\text { by } \\
\text { chemother } \\
\text { apy }\end{array}$ & $\begin{array}{l}\text { Not } \\
\text { done }\end{array}$ & $\begin{array}{l}\text { pT1 Primary } \\
\text { papillary } \\
\text { adenocarcinoma } \\
\text { No } \\
\text { lymphovascular } \\
\text { and perineural } \\
\text { invasion. }\end{array}$ & $\begin{array}{l}\text { Cytoplasm } \\
\text { positive for } \\
\text { CK20, } \\
\text { CK7,CD10 and } \\
\text { P5A: negative }\end{array}$ & $\begin{array}{l}\text { Died after } 6 \\
\text { months } \\
\text { following } \\
\text { surgery }\end{array}$ & Not known & Not known & $\begin{array}{l}6 \\
\text { months }\end{array}$ \\
\hline 59 & M & $\begin{array}{l}\text { Haematuri } \\
\text { a for more } \\
\text { than } 1 \\
\text { year }\end{array}$ & $\begin{array}{l}\text { CECT: } 2 \times \\
2.3 \times 2.1 \\
\mathrm{~cm} \text { nodule } \\
\text { in anterior } \\
\text { bladder } \\
\text { wall }\end{array}$ & $\begin{array}{l}\text { Partial } \\
\text { cystectomy }\end{array}$ & $\begin{array}{l}\text { Not } \\
\text { done }\end{array}$ & $\begin{array}{l}\text { PT2b Well } \\
\text { differentiated } \\
\text { adenocarcinoma. } \\
\text { No } \\
\text { lymphovascular } \\
\text { and perineural } \\
\text { invasion }\end{array}$ & Not done & $\begin{array}{l}\text { Alive at } 28 \\
\text { months } \\
\text { follow up } \\
\text { without } \\
\text { recurrence }\end{array}$ & $\begin{array}{l}>28 \\
\text { months }\end{array}$ & $>28$ months & $\begin{array}{l}>28 \text { mon } \\
\text { ths }\end{array}$ \\
\hline 54 & $F$ & $\begin{array}{l}\text { Painless } \\
\text { haematuri } \\
\text { a for } 2 \\
\text { months }\end{array}$ & $\begin{array}{l}\text { U55: } 2.7 \times \\
2.5 \times 2.3 \\
\mathrm{~cm} \\
\text { Anterior } \\
\text { bladder } \\
\text { wall } \\
\text { growth }\end{array}$ & $\begin{array}{l}\text { Partial } \\
\text { cystectomy }\end{array}$ & $\begin{array}{l}\text { Not } \\
\text { done }\end{array}$ & $\begin{array}{l}\text { pT4 Moderately } \\
\text { differentiated } \\
\text { leiomyosarcoma } \\
\text { invading the } \\
\text { rectus abdominis } \\
\text { muscle }\end{array}$ & $\begin{array}{l}\text { Positive for } \\
\text { smooth muscle } \\
\text { actin and } \\
\text { desmin. } \\
\text { Negative for } \\
\text { CD117. } \\
\text { The Ki67: 70- } \\
80 \% \text {. }\end{array}$ & $\begin{array}{l}\text { Alive with no } \\
\text { evidence of } \\
\text { recurrence } \\
\text { at } 3.5 \text { years }\end{array}$ & $\begin{array}{l}>42 \\
\text { months }\end{array}$ & $>42$ months & $\begin{array}{l}>42 \\
\text { months }\end{array}$ \\
\hline 60 & M & $\begin{array}{l}\text { Haematuri } \\
\text { a with } \\
\text { clots for } \\
11 \text { months }\end{array}$ & $\begin{array}{l}\text { US5: } 3.5 \times \\
3 \times 2.5 \mathrm{~cm} \\
\text { Dome and } \\
\text { anterior } \\
\text { wall mass } \\
\text { lesion }\end{array}$ & $\begin{array}{l}\text { Partial } \\
\text { cystectomy }\end{array}$ & $\begin{array}{l}\text { Not } \\
\text { done }\end{array}$ & $\begin{array}{l}\text { PT2 small cell } \\
\text { carcinoma with } \\
\text { squamous } \\
\text { differentiation }\end{array}$ & Not done & $\begin{array}{l}\text { Died at } 6 \\
\text { moths }\end{array}$ & 3 months & 3 months & $\begin{array}{l}6 \\
\text { months }\end{array}$ \\
\hline 34 & $M$ & $\begin{array}{l}\text { haematuri } \\
\text { a with } \\
\text { clots for } 5 \\
\text { months }\end{array}$ & $\begin{array}{l}\text { U55: } 6 \times 6 \\
\times 3 \mathrm{~cm} \\
\text { right } \\
\text { posterior } \\
\text { wall mass }\end{array}$ & $\begin{array}{l}\text { Partial } \\
\text { cystectomy } \\
\text { +limited } \\
\text { pelvic } \\
\text { lymphaden } \\
\text { ectomy } \\
\text { +sigmoid } \\
\text { colostomy } \\
\text { followed } \\
\text { by } \\
\text { chemother } \\
\text { apy }\end{array}$ & $\begin{array}{l}\text { Macros } \\
\text { copicall } \\
y \\
\text { enlarge } \\
\text { d nodes } \\
\text { were } \\
\text { remove } \\
d\end{array}$ & $\begin{array}{l}\text { pT4 Goblet cell } \\
\text { carcinoid tumour } \\
\text { of the bladder. } \\
\text { Pelvic lymph } \\
\text { nodes positive for } \\
\text { tumour }\end{array}$ & $\begin{array}{l}\text { Chromogranin } \\
\text { A: Occasional } \\
\text { positive cells, } \\
\text { PGP } 9.5 \text { Several } \\
\text { positive cells, } \\
\text { NSE negative }\end{array}$ & $\begin{array}{l}\text { Died at } 9 \\
\text { months }\end{array}$ & 3 months & - & $\begin{array}{l}9 \\
\text { months }\end{array}$ \\
\hline
\end{tabular}


had signet ring cell adenocarcinoma. Others had leiomyosarcoma, small cell cancer with squamous differentiation and goblet cell carcinoid tumour of the bladder. The majority $[\mathrm{n}=6]$ had muscle-invasive disease at surgery as confirmed by histopathology. The patients with signet ring cell carcinoma, leiomyosarcoma and well-differentiated adenocarcinoma had favourable outcomes [Table: 1], while patients with papillary carcinoma, small cell carcinoma and goblet cell carcinoid tumour showed poor outcomes. One patient with pT3b moderately differentiated adenocarcinoma had no CT evidence of recurrence at 4 months and was asymptomatic at nine months but thereafter, she was lost to follow up.

\section{Discussion}

Partial cystectomy is considered for selected urothelial carcinoma due to its function preservation and lesser surgical morbidity [3]. Recently, more cases of young patients with NUBC have been treated with partial cystectomy. However, they are restricted to a few case reports and series [4]. We reported our experience on partial cystectomy for NUBC which showed variable outcomes.

In our series, 4 patients had adenocarcinoma of the bladder. The adenocarcinoma of the bladder accounts for $0.5-2 \%$ of bladder cancers with the majority having a muscle-invasive disease. These are generally treated with radical cystectomy and pelvic lymph node dissection [5]. The 5-year overall survival rates are $10 \%$ to $60 \%$ for bladder adenocarcinomas. Of the different histological variants of adenocarcinoma, signet ring cell carcinoma is considered to have the worst outcomes [5]. In our series, 2 patients had a good outcome with no recurrence and of which, one patient had signet-ring cell carcinoma which is known to be associated with the worst prognosis. One patient was lost to follow up but the computed tomography [CT] at 4 months post-op did not show any recurrences. Papillary adenocarcinoma had the worst prognosis with overall survival of only 6 months.

Sarcomas are the commonest mesenchymal cancers of the bladder and leiomyosarcoma is the commonest histology variant. Although initial evidence suggested aggressive tumour biology, a recent larger case series of 35 patients, showed relatively favourable outcomes [recurrence rate-34\%, 5-year disease-specific survival-62\%] [6]. In our series, one patient had leiomyosarcoma of the bladder and had an excellent outcome with no detectable recurrence at 5 years.

Neuroendocrine carcinoma of the urinary bladder is very rare, accounting for only $0.35-0.70 \%$ of all bladder cancers and is further subdivided into small cell and large cell carcinoma [7]. To date, there is no standard treatment for the disease because of a lack of data due to the rarity of the disease. In a multi- institutional review of 64 patients in the United States 5-year disease-specific survival rates among patients who underwent radical cystectomy was only $16 \%$. Furthermore, the place for cystectomy is doubtful as there is no difference in survival between patients who underwent cystectomy and patients without surgery [7]. Our patient with muscleinvasive small cell carcinoma had a poor outcome with overall survival of only 6 months. Another patient with a goblet cell carcinoid tumour of the bladder also had a poor outcome.

There are no large scale prospective studies analyzing the effectiveness of partial cystectomy for NUBC and current evidence is only restricted to few case reports and case series. We reported our experience which showed variable outcomes following partial cystectomy for NUBC. In our series, some tumours which are believed to have a worse prognosis such as signet ring cell carcinoma and leiomyosarcoma had good outcomes following partial cystectomy. Radical cystectomy is associated with high morbidity due to surgery and poor quality of life and may not be suitable for patients with significant comorbidities. In future, with advances in early detection and accurate staging, partial cystectomy may be offered for selected patients with early NUBC. However, further studies will be required to study the role of partial cystectomy for NUBC in terms of factors associated with outcome and patient selection.

\section{Conclusion}

In this series of NUBC, partial cystectomy was associated with variable outcomes. Careful patient selection with specific emphasis on the tumour type, location and staging with prior patient counselling is mandatory. Further analyses are necessary to understand the factors associated with good outcomes following partial cystectomy which would be helpful in patient selection.

All authors disclose no conflict of interest. The study was conducted in accordance with the ethical standards of the relevant institutional or national ethics committee and the Helsinki Declaration of 1975, as revised in 2000 .

\section{References}

1. Jayarajah U, Herath K, Fernando M, Kuruppu S, Wickramanayaka U, Fernando I, et al. A clinico-pathological study of non-urothelial bladder cancers in a cohort of patients from a tertiary care urology unit in Sri Lanka. Ceylon Medical Journal. 2018;63[2]:92-4. https://doi.org/10.4038/cmj.v63i2.8680

2. Fernando $\mathrm{MH}$, Jayarajah U, Herath $\mathrm{KB}$, de Silva MVC, Goonewardena SAS. Aggressive squamous cell carcinoma of the bladder associated with a history of large bladder stone-a case report. Clinical case reports. 2017;5[10]:1616. 
https://doi.org/10.1002/ccr3.1133

3. Bazzi W M, Kopp RP, Donahue TF, Bernstein M, Russo P, Bochner $\mathrm{BH}$, et al. Partial cystectomy after neoadjuvant chemotherapy: Memorial Sloan Kettering Cancer Center contemporary experience. International scholarly research notices. 2014;2014. https://doi.org/10.1155/2014/702653

4. Jayarajah U, Fernando MH, Herath KB, de Silva VC, Goonewardena SAS. Partial cystectomy for a primary locally advanced leiomyosarcoma of the bladder: a case report and review of the literature. Clinical Case Reports. 2018;6[5]:883. https://doi.org/10.1002/ccr3.1476
5. Dadhania V, Czerniak B, Guo CC. Adenocarcinoma of the urinary bladder. American Journal of Clinical and Experimental Urology. 2015;3[2]:51-63.

https://www.ncbi.nlm.nih.gov/pmc/articles/PMC4539107/

6. Rosser CJ, Slaton JW, Izawa JI, Levy LB, Dinney CP. Clinical presentation and outcome of high-grade urinary bladder leiomyosarcoma in adults. Urology. 2003;61[6]:1151-5. https://doi.org/10.1016/s0090-4295[03]00021-9

7. Cheng L, Pan CX, Yang XJ, Lopez-Beltran A, MacLennan GT, Lin H, et al. Small cell carcinoma of the urinary bladder. Cancer. 2004;101[5]:957-62. https://doi.org/10.1002/cncr.20456 